\title{
Soil Test Phosphorus Recovery from Livestock Manures Compared with Inorganic Fertilizer in Soil Incubations
}

\author{
J. Craig Miller, ${ }^{1}$ T. Astatkie, ${ }^{2}$ and Ali Madani ${ }^{2}$ \\ ${ }^{1}$ Department of Plant and Animal Sciences, Nova Scotia Agricultural College, P.O. Box 550, Truro, NS, Canada B2N 5E3 \\ ${ }^{2}$ Department of Engineering, Nova Scotia Agricultural College, P.O. Box 550, Truro, NS, Canada B2N 5E3
}

Correspondence should be addressed to T. Astatkie, tastatkie@nsac.ca

Received 17 March 2010; Revised 21 June 2010; Accepted 30 August 2010

Academic Editor: Paul Voroney

Copyright ( 2010 J. Craig Miller et al. This is an open access article distributed under the Creative Commons Attribution License, which permits unrestricted use, distribution, and reproduction in any medium, provided the original work is properly cited.

\begin{abstract}
This paper compared dairy and hen manure P recovery relative to fertilizer P recovery for two Nova Scotia soils with different antecedent soil test $\mathrm{P}$ (STP), incubated for 5, 15, 30, 60, and 110 days. Fertilizer equivalence of manure $\mathrm{P}$ was expressed as $\mathrm{P}$ recovery ratio in percentage points (\%PRR). Repeated measures analysis with soil $\mathrm{pH}$ covariate revealed: (1) manure \%PRR averaged $72 \%$ (low-STP soil) and 80\% (medium-STP soil), (2) there were no significant differences in \%PRR between dairy and hen manure, and (3) manure \%PRR decreased with incubation time for the low-STP soil but not for the medium-STP soil. The soil pH covariate was significant for both low- and medium-STP soils, and the relationship with \%PRR was positive for low- but not for the mediumSTP soil.
\end{abstract}

\section{Introduction}

The traditional approach of basing manure applications on $\mathrm{N}$ content leads to the buildup of soil $\mathrm{P}$ to levels that pose a pollution hazard. As a result, many jurisdictions have adopted P-based nutrient management planning regulations for intensive livestock operations. P-based nutrient management seeks to match $\mathrm{P}$ application to crop $\mathrm{P}$ requirements as indicated by soil testing. However, soil test P recommendations are based on crop response to inorganic fertilizer $\mathrm{P}$ and there is lack of agreement on the equivalence between manure $\mathrm{P}$ and fertilizer $\mathrm{P}$.

While some studies have found that livestock manures were equivalent to inorganic fertilizer in P availability [1-4], others [5-8] have reported results that indicate that manure $\mathrm{P}$ was generally less available than inorganic fertilizer $\mathrm{P}$. Laboski and Lamb [9] found that availability of soil P from injected swine manure was greater than that from fertilizer $\mathrm{P}$ for incubation periods of 1 to 9 months, with the difference between the two $\mathrm{P}$ sources increasing over time.

Some of the differences in results may be attributed to experimental conditions. Goss and Stewart [10] found that plants grown in superphosphate-amended soil removed a higher percentage of added $\mathrm{P}$ than in manure-amended soil, partly because of luxury consumption. On the other hand, Sikora and Enkiri [11] found no significant overall differences between poultry litter compost and triple superphosphate fertilizer in plant cumulative P uptake; however, the soil used was already high to excessive in STP. The choice of fertilizer used for comparison can have an effect on the estimated fertilizer equivalence of manure $\mathrm{P}[12,13]$. Reagents used for soil extraction also differ in the amounts and forms of $\mathrm{P}$ they recover $[12,14]$.

Environmental conditions also play a role. For example, Blake et al. [15] suggested that manure $\mathrm{P}$ can be either less available or more available than superphosphate $\mathrm{P}$, depending on climate, soil, and availability of other plant nutrients and advised careful consideration of environmental conditions when transferring conclusions about soil $\mathrm{P}$ availability from one environment to another. Others $[6$, 16] identified the effect of degree of soil P-saturation on release of soluble P where soils with higher initial STP and thus a greater degree of $\mathrm{P}$ saturation maintained a higher proportion of added $\mathrm{P}$ in available form.

The type of the manure, itself, can have a bearing on the availability of its $\mathrm{P}[6,14,17,18]$, with manure $\mathrm{Ca}$ content identified as an important determinant of manure $\mathrm{P}$ availability $[17,18]$. 
TABLE 1: Selected properties of Medium-Soil Test P (Med-STP) and Low-Soil Test P (Low-STP) soils used in the study. Lab analysis was performed on the bulked, dried, and sieved soil.

\begin{tabular}{|c|c|c|c|c|c|c|c|c|}
\hline \multirow{2}{*}{ Soil } & \multicolumn{2}{|c|}{ Soil Taxonomy } & \multirow{2}{*}{ Soil Texture } & \multirow{2}{*}{$\mathrm{pH}$} & \multirow[t]{2}{*}{$\% \mathrm{SOM}$} & \multicolumn{3}{|c|}{ Soil Test values $\left(\mathrm{mg} \mathrm{kg}^{-1}\right)^{(\mathrm{a})}$} \\
\hline & Canadian & U.S.D.A. & & & & $\mathrm{P}$ (rating) & $\mathrm{Ca}$ (rating) & $\mathrm{Fe}$ \\
\hline Med & Gleyed Humic & Humaquent & coarse & 6.7 & 2.7 & 38 & 3828 & 336 \\
\hline STP & Regosol & & loamy & & & (medium) & $($ medium +$)$ & \\
\hline Low & Gleyed Humic & Humaquent & coarse & 4.9 & 3.8 & $23($ low -$)$ & $2014($ low +$)$ & 430 \\
\hline STP & Regosol & & loamy & & & & & \\
\hline
\end{tabular}

${ }^{(a)}$ Soil test values by Mehlich-3 extraction. Ratings shown in bracket indicate the magnitude of these values.

TABle 2: Properties of Phosphorus sources.

\begin{tabular}{|c|c|c|c|c|}
\hline Phosphorus Source & $\% \mathrm{P}^{(\mathrm{a})}$ & $\%$ dry matter & $\mathrm{pH}$ & $\% \mathrm{Ca}$ \\
\hline $\mathrm{Ca}\left(\mathrm{H}_{2} \mathrm{PO}_{4}\right)_{2} \cdots \mathrm{H}_{2} \mathrm{O}(\mathrm{MCP})$ & $24.6 \%$ & - & - & 15.9 \\
\hline Dairy Manure (DM) & 0.046 to $0.058 \%$ & 11.06 to 11.84 & 6.7 to 6.9 & 0.118 \\
\hline Layer Hen Manure (HM) & 0.358 to $0.476 \%$ & 28.66 to 30.08 & 6.8 to 8.4 & 1.84 \\
\hline
\end{tabular}

${ }^{(a)}$ Manure analysis on a wet weight basis.

The question of fertilizer equivalence of manure $\mathrm{P}$ sources is determined more definitively by crop responses in field trials using manure; however, such research requires large expenditures of time and labor. Sharpley and Sisak [8] suggested that rather than repeating field trials with manure $\mathrm{P}$, equivalence could be determined more economically by laboratory comparisons with fertilizer P, and Zvomuya et al. [3] suggested that a few simple chemical measurements could predict manure $\mathrm{P}$ availability. Soil incubation studies offer a low-cost alternative to field studies, while allowing for better control over variables. Used in concert with data from existing field trials they can provide a basis for estimating manure $\mathrm{P}$ applications for optimum crop growth.

This study used soil incubations to try to establish fertilizer equivalence of two different sources of manure $\mathrm{P}$ based on Mehlich-3 (M3) STP in order that soil-test ratings may be used to more accurately determine the optimum manure $\mathrm{P}$ applications. It also attempts to address temporal differences in $\mathrm{P}$ availability by incubating the P-amended soil with repeated sampling over a period of 110 days. In order to assess the effects of antecedent soil $\mathrm{P}$ status on availability of added $\mathrm{P}$, this study used similar soils with different antecedent STP ratings. The effects of soil $\mathrm{pH}$ on manure $\mathrm{P}$ fertilizer equivalence was also investigated.

Many of the studies cited herein used very high $\mathrm{P}$ levels associated with manure application rates required for disposal in intensive livestock operations, or even higher rates. Several researchers $[2,3,6,8-10,16,18,19]$ applied manure $\mathrm{P}$ at levels as high as $1200,800,288,154,108,100$, 150,280 , and $200 \mathrm{mg} \mathrm{Pg}^{-1}$ soil, respectively. Because of changes in soil chemistry and biochemistry brought about by such high rates of amendments, their results may not be applicable for manure $\mathrm{P}$ application at rates equivalent to crop $\mathrm{P}$ removal. This study is different in that it used much lower $\mathrm{P}$ application rates, according to crop nutrient requirements based on soil testing.

The overall objective of this study was to determine the effect of source of manure and rate of application on $\mathrm{P}$ recovery from manure relative to fertilizer over a growing season.

\section{Materials and Methods}

2.1. Soil Characteristics and Preparation. Two field soils from the Acadia association [20] located on dyked farmland (reclaimed salt marsh) near Truro, Nova Scotia $\left(45^{\circ} 14^{\prime} \mathrm{N}\right.$, $63^{\circ} 19^{\prime} \mathrm{W}$ ), cropped to perennial mixed forages, were collected from $0-15 \mathrm{~cm}$ depth. Soil properties are shown in Table 1. Soils were selected for different STP ratings: low- and medium STP-soils. Bulked soil was dried at about $70^{\circ} \mathrm{C}$ for 1 week and sieved through $6 \mathrm{~mm}$ mesh prior to setting up the incubations.

2.2. Phosphorus Treatments. Nine different soil $P$ treatments, each replicated three times, were applied to each soil: laboratory grade monocalcium phosphate (MCP), solid layer hen manure (HM), and liquid dairy manure (DM), each at 3 different rates. $\mathrm{P}$ application levels were approximately $1 / 2 \times, 1 \times$, and $1.5 \times$ (representing low (1), medium (2), and high (3)) P requirements for spring feed barley for each soil, according to Nova Scotia Department of Agriculture STP ratings and plant nutrient requirement data. Properties of $\mathrm{P}$ sources are shown in Table 2 and $\mathrm{P}$ application rates are shown in Table 3.

Phosphorus treatments were dissolved or suspended in 350 to $400 \mathrm{~mL}$ water (to obtain soil moisture tension of about $20 \mathrm{kPa}$ ) which was sprinkled onto $1.25 \mathrm{~kg}$ dry soil in a shallow tray. The soil was then mixed for 10 minutes with a garden trowel until the soil was uniformly moist with aggregates less than about $2 \mathrm{~cm}$ diameter.

The treated soil samples were transferred into $2 \mathrm{~L}$ plastic tubs with perforated lids and incubated in a growth chamber in a completely randomized distribution for each soil at ambient room temperature (approximately $20^{\circ} \mathrm{C}$ ) and soil moisture tension between $16 \mathrm{kPa}$ and $24 \mathrm{kPa}$ for the duration of the experiment (110 days). Gravimetric soil moisture 
TABle 3: Phosphorus application rates with low, medium, and high approximately equal to $1 / 2 \times, 1 \times$, and $1.5 \times$ the recommended $\mathrm{P}$ rate for spring feed barley, respectively.

\begin{tabular}{lccccccc}
\hline \multirow{2}{*}{ Soil } & \multicolumn{5}{c}{ Phosphorus application rates } \\
& P source & Low & $\begin{array}{c}\text { mg P/kg soil } \\
\text { Medium }\end{array}$ & High & Low & Equivalent kg $\mathrm{P}_{2} \mathrm{O}_{5} / \mathrm{ha}$-fs \\
Medium & High \\
\hline \multirow{2}{*}{ Medium STP } & MCP & 8 & 17 & 25 & 38 & 76 & 115 \\
& DM & - & 15 & 22 & - & 69 & 103 \\
\multirow{4}{*}{ Low STP } & HM & 10 & 20 & 30 & 46 & 92 & 137 \\
& MCP & 10 & 21 & 31 & 47 & 94 & 142 \\
& DM & - & 22 & 33 & - & 100 & 150 \\
& HM & 14 & 28 & 42 & 64 & 128 & 191 \\
\hline
\end{tabular}

Table 4: Soil Test P (ppm) values for the control, as well as the fertilizer, the dairy manure, and the hen manure sources and their application rates at the five incubation times. The shown values are averages of three replications.

\begin{tabular}{|c|c|c|c|c|c|c|c|c|c|c|c|}
\hline \multirow[t]{2}{*}{ Source } & \multirow[t]{2}{*}{ Rate } & \multicolumn{5}{|c|}{$\begin{array}{c}\text { Low STP soil } \\
\text { Incubation time (days) }\end{array}$} & \multicolumn{5}{|c|}{$\begin{array}{c}\text { Medium STP soil } \\
\text { Incubation time (days) }\end{array}$} \\
\hline & & 5 & 15 & 30 & 60 & 110 & 5 & 15 & 30 & 60 & 110 \\
\hline Control & 0 & 56 & 59 & 53 & 77 & 85 & 49 & 53 & 45 & 56 & 62 \\
\hline $\mathrm{MCP}$ & 1 & 62 & 71 & 60 & 76 & 87 & 56 & 54 & 49 & 65 & 69 \\
\hline MCP & 2 & 68 & 72 & 63 & 92 & 93 & 60 & 58 & 54 & 62 & 67 \\
\hline MCP & 3 & 74 & 82 & 74 & 87 & 104 & 63 & 64 & 54 & 70 & 68 \\
\hline $\mathrm{DM}$ & 2 & 67 & 72 & 60 & 80 & 90 & 57 & 55 & 49 & 58 & 69 \\
\hline $\mathrm{DM}$ & 3 & 72 & 82 & 67 & 76 & 95 & 59 & 60 & 51 & 64 & 68 \\
\hline HM & 1 & 65 & 68 & 59 & 78 & 89 & 53 & 51 & 47 & 60 & 66 \\
\hline HM & 2 & 73 & 78 & 62 & 86 & 96 & 57 & 57 & 51 & 66 & 66 \\
\hline HM & 3 & 80 & 83 & 68 & 91 & 96 & 64 & 62 & 55 & 70 & 73 \\
\hline
\end{tabular}

content was monitored by weighing the soil pots before each sampling and adding water to keep incubations within soil moisture tension range, if necessary.

2.3. Repeated Sampling. After 5, 15, 30, 60, and 110 days of incubation, each container was emptied into a shallow tray and mixed thoroughly. A 150 to $200 \mathrm{~g}$ (moist weight) soil subsample was removed from the tray for analysis. The rest of the soil was returned to the container and incubator.

2.4. Manure Analysis. Manure mineral content was determined at Laboratory Services of the Nova Scotia Department of Agriculture in Truro, Nova Scotia, by modified AOAC method 968.08 [21]. Samples were prepared by first adjusting the $\mathrm{pH}$ to 2 with $50 \% \mathrm{H}_{2} \mathrm{SO}_{4}$. The acidified samples were dried at $95^{\circ} \mathrm{C}$ and ground in a Wiley mill with $2 \mathrm{~mm}$ mesh, and a $0.75 \mathrm{~g}$ subsample was then ashed in a muffle furnace at $550^{\circ} \mathrm{C}$ for 5 hours. One $\mathrm{mL}$ concentrated $\mathrm{HCl}$ was added to the ash and after 5 minutes. the mixture was brought up to $75 \mathrm{~mL}$ with deionized water and shaken; and then allowed to sit for 30 minutes before determination of mineral content on a Jarrel-Ash Model 9000 Inductively Coupled Argon Plasma Optical Emission Spectrometer (ICAP).

2.5. Soil Analysis. The STP and soil $\mathrm{pH}$ were determined by the Laboratory Services of the Nova Scotia Department of Agriculture. A $2.5 \mathrm{~mL}$ subsample of dried $\left(105^{\circ} \mathrm{C}\right)$ ground (to pass $2 \mathrm{~mm}$ mesh) soil was mixed with $25 \mathrm{~mL}$ Mehlich3 solution [22]. The mixture was shaken for 5 minutes on reciprocating shaker at 240 oscillations/min, and then filtered through no. 5 Watman filter paper. The filtrate was analyzed for P by ICAP. Mean values of STP at the different incubation times are shown in Table 4 to indicate the magnitude of differences among the treatments. However, percentages of Recovery Ratio values calculated as indicated in the following section are analyzed. It should be noted that STP values for control treatment were higher after incubation than those observed prior to the inception of the study, and that the relative STP values for the two soils changed following incubation.

Soil $\mathrm{pH}$ was determined with an Orion W-BNC combination electrode. Twenty $\mathrm{mL}$ of dry, sieved $(2 \mathrm{~mm})$ soil were mixed with $20 \mathrm{~mL}$ deionized water, stirred intermittently for 30 minutes. and allowed to settle for 30 minutes before $\mathrm{pH}$ determination in the supernatant.

2.6. Statistical Analyses. For each soil, incubation duration, $\mathrm{P}$ treatment, and replication, \% $\mathrm{P}$ recovery was calculated as $($ (treatment STP - unamended control STP $) \div$ added P $) \times$ $100 \%$, and then the average of the 3 replications for each of MCP1, MCP2, and MCP3 was used to calculate the corresponding manure $\mathrm{P}$ recovery ratio (\%PRR) response as: ( $\% \mathrm{P}$ recovery for manure treatment $\div \%$ Precovery) $\times 100 \%$ for equivalent P-fertilizer treatment. \%PRR was converted 
TABle 5: ANOVA $P$-values that show the main and interaction effects of Source of P (Source), Rate of application (Rate), and Incubation time (Day) as well as the linear and quadratic coefficients of the covariate on \%PRR. Significant effects that require further multiple means comparison are shown in bold.

\begin{tabular}{lcc}
\hline Source of variation & Low-STP soil & Medium-STP soil \\
\hline Source & 0.857 & 0.609 \\
Rate & 0.285 & 0.303 \\
Source $*$ Rate & 0.134 & 0.934 \\
Day & 0.001 & 0.033 \\
Source $*$ Day & $\mathbf{0 . 0 0 4}$ & 0.002 \\
Rate $*$ Day & 0.544 & 0.002 \\
Source $*$ Rate $*$ Day & 0.389 & $\mathbf{0 . 0 0 9}$ \\
pH & 0.003 & 0.001 \\
pH squared & 0.004 & 0.001 \\
\hline
\end{tabular}

to mass basis using the bulk density of dried ground sieved soil subsamples. For each soil, \%PRR response was analyzed as repeated measures analysis of unbalanced twofactor factorial design with two levels of Source of P (DM, HM) and three Rates of application (1, 2, and 3), and 5 durations (Day: 5, 15, 30, 60, and 110 days) with a second order polynomial of soil $\mathrm{pH}$ covariate (by using $\mathrm{pH}$ and $\mathrm{pH}$-squared values as covariates). In this repeated measures analysis, the error terms were assumed to have a normal distribution with constant variance, but dependence among them expressed with the most appropriate covariance structure. For both soils, based on the Akaike's Information Criterion (AIC) and Schwarz's Bayesian Criterion (SBC), [23], the most appropriate covariance structure was determined to be Unstructured (UN). The normal distribution and constant variance assumptions on the error terms were verified by examining the residuals [24]. Since the covariates were significant (Table 5), the least squared means that are adjusted for the covariate were compared and letter groupings generated. The MIXED Procedure in SAS [25] was used to complete the analysis. The relationships between $\% \mathrm{PRR}$ and the covariates were further explored to determine whether the relationship was positive or negative.

\section{Results and Discussion}

Overall, manure \%PRR was 72\% for the low-STP soil and $80 \%$ for the medium-STP soil (averaged over all manure treatments). However, the effect of the treatments varied with incubation period for the low STP, but not for the medium STP.

3.1. Effect of Source, Rate, and Incubation Time on $\% P R R$. The interaction effect of source, rate, and incubation time was significant for medium STP soil; but only the interaction effect of source and incubation time was significant for the low STP soil (Table 5) suggesting that the effect of source (for the low STP soil) and source by rate combination (for the medium STP soil) changed during the incubation period. The \%PRR showed dramatic change for the low STP soil compared to that for the medium STP soil (Figure 1).
However, there was no difference among the rates for the low STP soil, and the pattern of the differences among the rates in the medium STP soil was not discernible.

Redding et al. [26] identified a similar temporal effect on $P$ sorption by soil incubated with pig manure effluent. They found that piggery effluent temporarily increased vulnerability of soil $\mathrm{P}$ to desorption, but that the effect was lost after 2 to 113 days of incubation. Guppy et al. [27] found a temporary suppression (lasting less than 6 days) of $\mathrm{P}$ sorption by fulvic acid components of plant leachates added to two Oxisols whereas [28] observed that maximum STP (Olsen extraction) from addition of pig manure compost occurred at 30 days incubation and declined rapidly thereafter in a moderately acid soil.

Laboski and Lamb [9] observed effects opposite to those seen in Figure 1. They found that fertilizer $\mathrm{P}$ availability decreased while swine manure $\mathrm{P}$ availability was unchanged over 1 to 9 months of incubation for 6 of the 7 Minnesota soils used in their study. This would result in increasing manure \%PRR over time; however, comparisons with their results are tenuous because their $\mathrm{P}$ application rates averaged about one order of magnitude greater than those used in this study.

3.2. Effect of Soil $p H$ on $\% P R R$. Initial $\mathrm{pH}$ differences caused significant differences in the \%PRR of manure P treatments for low- as well as medium-STP soils (Table 5). Second order polynomial regression of $\% \mathrm{PRR}$ on soil $\mathrm{pH}$ (Figure 2) for the manure treatments in the low-STP soil indicated that fertilizer equivalence of manure $\mathrm{P}$ increased with soil $\mathrm{pH}$ that ranged between 4.2 and 5.4. Although manure $\mathrm{P}$ was mainly lower in availability than fertilizer $\mathrm{P}$ throughout the $\mathrm{pH}$ range found in this soil, the difference narrowed as soil $\mathrm{pH}$ increased. Tan et al. [29] found that the metal complexing capacity and stability of metal complexes formed by water extract of poultry manure increased with increasing $\mathrm{pH}$. Increasing binding of soil $\mathrm{Fe}$ and $\mathrm{Al}$ in organometal complexes at higher $\mathrm{pHs}$ might explain the relationship between \%PRR and soil $\mathrm{pH}$ in the low-STP soil as seen in Figure 2. The $\mathrm{pH}$ range for the medium STP soil $(6.3$ to 6.9) was rather narrow and falls in the range where $P$ availability often rises and falls with increasing soil $\mathrm{pH}$. It was not surprising to see a curved pattern depicted in Figure 2.

Lower molecular weight (MW) dissolved organic matter may be most effective in complexing metals [30]. Low MW organics released from manure by mineralization in the medium STP soil (with neutral pH) could be responsible for the suppressing $\mathrm{P}$ fixation in the manure treatments; whereas, in the low-STP soil, mineralization was retarded by the low $\mathrm{pH}(4.2-5.4)$, so that low-MW organics did not accumulate. This conclusion is also consistent with findings of Tan et al. [29]: that the metal complexing capacity and stability of complexes formed with manure extracts increased with increasing soil $\mathrm{pH}$.

On the other hand, organometal complexes may also form new P-sorption sites, which is important because it was shifts in soil P-sorption isotherms that led Guppy et al. [27] to hypothesize that formation of metal chelates may have increased $\mathrm{P}$ adsorption in highly weathered soils. Although 

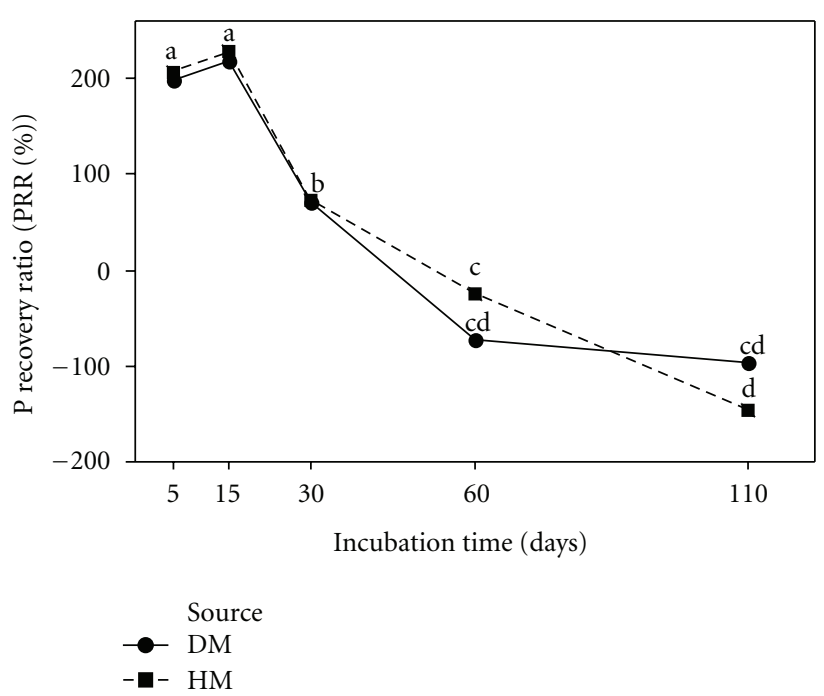

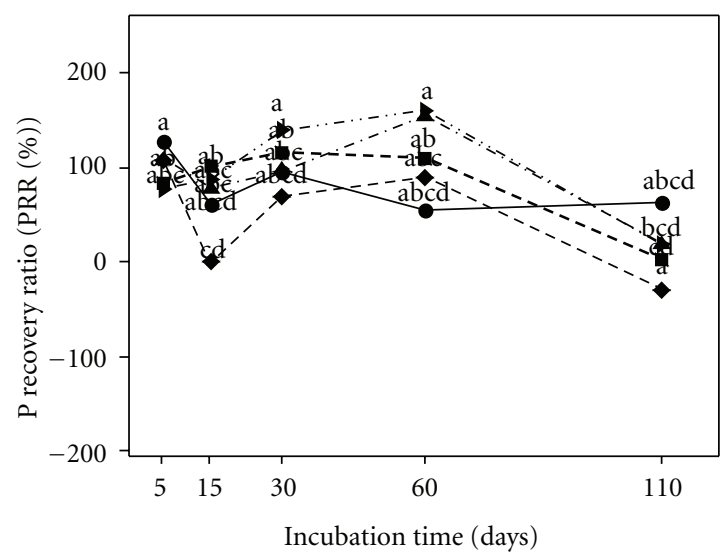

$\begin{array}{lll} & \text { Source } & \text { Rate } \\ - \text { DM } & 2 \\ -\square- & \text { DM } & 3 \\ - & \text { HM } & 1 \\ - \text { - HM } & 2 \\ \rightarrow- & \text { HM } & 3\end{array}$

(b) Medium STP soil

Figure 1: \% P Recovery Ratio (\%PRR) for the two sources of manure (low-STP soil) and the five combination of source of manure and application rate (medium-STP soil) at the five incubation periods. Within each soil, means sharing the same letter are not significantly different.

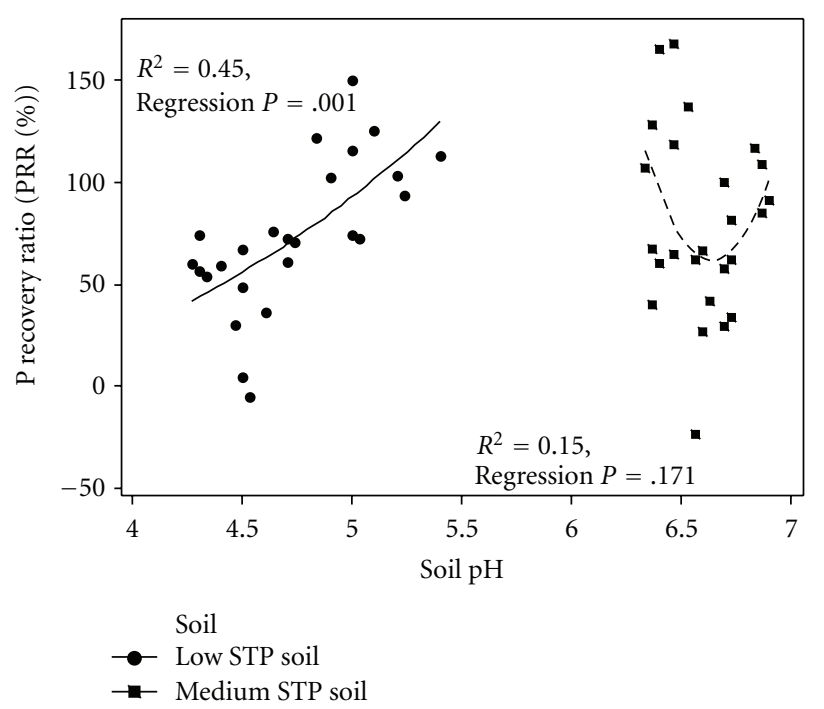

Figure 2: Plot of the percentage of P-Recovery Ratio versus Soil pH along with fitted second order polynomial regression line. The data points are averages of the three replication of the $\mathrm{P}$ treatment by incubation time combinations.

the soils in this study were relatively young, the low-STP soil results are consistent with this hypothesis.

\section{Conclusions}

This paper indicated that based on M3 extraction, $\mathrm{P}$ from poultry and dairy manures was less available than MCP-P (\%PRR less than 100\%). The overall average \%PRR for the two sources of manure and the two soils was $75 \%$, however, the fertilizer equivalence of manure P (\%PRR) varied depending on resident time in soil and soil $\mathrm{pH}$ as well as the soil chemistry. Fertilizer available P increased with incubation period at a faster rate than manure available P in the low-STP soil, but not as fast in the medium-STP soil. Depending on the combination of factors and the nature of the soil, manure $\mathrm{P}$ may be much less available or even more available than MCP fertilizer. Soil $\mathrm{P}$ dynamics is very complex and warrants further research.

\section{References}

[1] B. Eghball, B. J. Wienhold, B. L. Woodbury, and R. A. Eigenberg, "Plant availability of phosphorus in swine slurry and cattle feedlot manure," Agronomy Journal, vol. 97, no. 2, pp. 542-548, 2005.

[2] L. J. Sikora and N. K. Enkiri, "Comparison of phosphorus uptake from poultry litter compost with triple superphosphate in codorus soil," Agronomy Journal, vol. 97, no. 3, pp. 668-673, 2005.

[3] F. Zvomuya, B. L. Helgason, F. J. Larney, H. H. Janzen, O. O. Akinremi, and B. M. Olson, "Predicting phosphorus availability from soil-applied composted and non-composted cattle feedlot manure," Journal of Environmental Quality, vol. 35, no. 3, pp. 928-937, 2006.

[4] E. G. Sneller and C. A. M. Laboski, "Phosphorus source effects on corn utilization and changes in soil test," Agronomy Journal, vol. 101, no. 3, pp. 663-670, 2009.

[5] H. I. Gracey, "Availability of phosphorus in organic manures compared with monoammonium phosphate," Agricultural Wastes, vol. 11, no. 2, pp. 133-141, 1984. 
[6] T. S. Griffin, C. W. Honeycutt, and Z. He, "Changes in soil phosphorus from manure application," Soil Science Society of America Journal, vol. 67, no. 2, pp. 645-653, 2003.

[7] P. P. Motavalli, K. A. Kelling, and J. C. Converse, "First-year nutrient availability from injected dairy manure," Journal of Environmental Quality, vol. 18, no. 2, pp. 180-185, 1989.

[8] A. N. Sharpley and I. Sisak, "Differential availability of manure and inorganic sources of phosphorus in soil," Soil Science Society of America Journal, vol. 61, no. 5, pp. 1503-1508, 1997.

[9] C. A. M. Laboski and J. A. Lamb, "Changes in soil test phosphorus concentration after application of manure or fertilizer," Soil Science Society of America Journal, vol. 67, no. 2, pp. 544-554, 2003.

[10] D. W. Goss and B. A. Stewart, "Efficiency of phosphorus utilization by alfalfa from manure and superphosphate," Soil Science Society of America Journal, vol. 43, pp. 523-528, 1979.

[11] L. J. Sikora and N. K. Enkiri, "Availability of poultry litter compost P to fescue compared with triple super phosphate," Soil Science, vol. 168, no. 3, pp. 192-199, 2003.

[12] R. C. Schwartz and T. H. Dao, "Phosphorus extractability of soils amended with stockpiled and composted cattle manure," Journal of Environmental Quality, vol. 34, no. 3, pp. 970-978, 2005.

[13] V. R. Haden, Q. M. Ketterings, and J. E. Kahabka, "Factors affecting change in soil test phosphorus following manure and fertilizer application," Soil Science Society of America Journal, vol. 71, no. 4, pp. 1225-1232, 2007.

[14] A. N. Sharpley, R. W. McDowell, and P. J. A. Kleinman, "Amounts, forms, and solubility of phosphorus in soils receiving manure," Soil Science Society of America Journal, vol. 68, no. 6, pp. 2048-2057, 2004.

[15] L. Blake, S. Mercik, M. Koerschens et al., "Phosphorus content in soil, uptake by plants and balance in three European longterm field experiments," Nutrient Cycling in Agroecosystems, vol. 56, no. 3, pp. 263-275, 2000.

[16] D. H. Pote, J. A. Lory, and H. Zhang, "Does initial soil P level affect water-extractable soil $\mathrm{P}$ response to applied P?" Advances in Environmental Research, vol. 7, no. 2, pp. 503-509, 2003.

[17] A. B. Leytem and D. T. Westermann, "Phosphorus availability to barley from manures and fertilizers on a calcareous soil," Soil Science, vol. 170, no. 6, pp. 401-412, 2005.

[18] M. T. Siddique and J. S. Robinson, "Phosphorus sorption and availability in soils amended with animal manures and sewage sludge," Journal of Environmental Quality, vol. 32, no. 3, pp. 1114-1121, 2003.

[19] J. K. Whalen, C. Chang, G. W. Clayton, and J. P. Carefoot, "Cattle manure amendments can increase the $\mathrm{pH}$ of acid soils," Soil Science Society of America Journal, vol. 64, no. 3, pp. 962966, 2000.

[20] K. T. Webb, R. L. Thompson, G. J. Beke, and J. L. Nowland, "Soils of colchester county, Nova Scotia," Tech. Rep. 19, Nova Scotia Soil Survey, Research Branch, Agriculture Canada, Ottawa, Canada, 1991.

[21] W. Horowitz and G. W. Latimer, Eds., Official Methods of Analysis of AOAC, AOAC International, Gaithersburg, Md, USA, 18th edition, 2005.

[22] A. Mehlich, "Mehlich 3 soil test extractant: a modification of Mehlich 2 extractant," Communications in Soil Science \& Plant Analysis, vol. 15, no. 12, pp. 1409-1416, 1984.

[23] R. C. Littell, P. R. Henry, and C. B. Ammerman, "Statistical analysis of repeated measures data using SAS procedures," Journal of Animal Science, vol. 76, no. 4, pp. 1216-1231, 1998.

[24] D. C. Montgomery, Design and Analysis of Experiments, Wiley, New York, NY, USA, 7th edition, 2009.
[25] SAS Institute Inc., SAS OnlineDoc ${ }^{\circledR}$, Version 9.1, SAS Institute Inc., Cary, NC, USA, 2003.

[26] M. R. Redding, T. Shatte, and K. Bell, "Soil sorptiondesorption of phosphorus from piggery effluent compared with inorganic sources," European Journal of Soil Science, vol. 57, no. 2, pp. 134-146, 2006.

[27] C. N. Guppy, N. W. Menzies, F. P. C. Blamey, and P. W. Moody, "Do decomposing organic matter residues reduce phosphorus sorption in highly weathered soils?" Soil Science Society of America Journal, vol. 69, no. 5, pp. 1405-1411, 2005.

[28] B. Guo, Y. Liang, Z. Li, and F. Han, "Phosphorus adsorption and bioavailability in a paddy soil amended with pig manure compost and decaying rice straw," Communications in Soil Science and Plant Analysis, vol. 40, no. 13-14, pp. 2185-2199, 2009.

[29] K. H. Tan, R. A. Leonard, A. R. Bertrand, and S. R. Wilkinson, "The metal complexing capacity and the nature of the chelating ligands of water extract of poultry litter," Soil Science Society of America Journal, vol. 35, pp. 265-269, 1971.

[30] T. Ohno and B. S. Crannell, "Green and animal manurederived dissolved organic matter effects on phosphorus sorption," Journal of Environmental Quality, vol. 25, no. 5, pp. 1137-1143, 1996. 

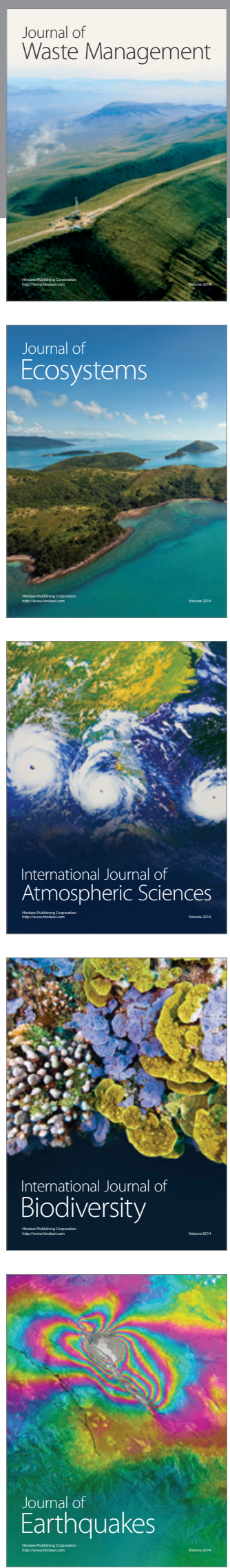
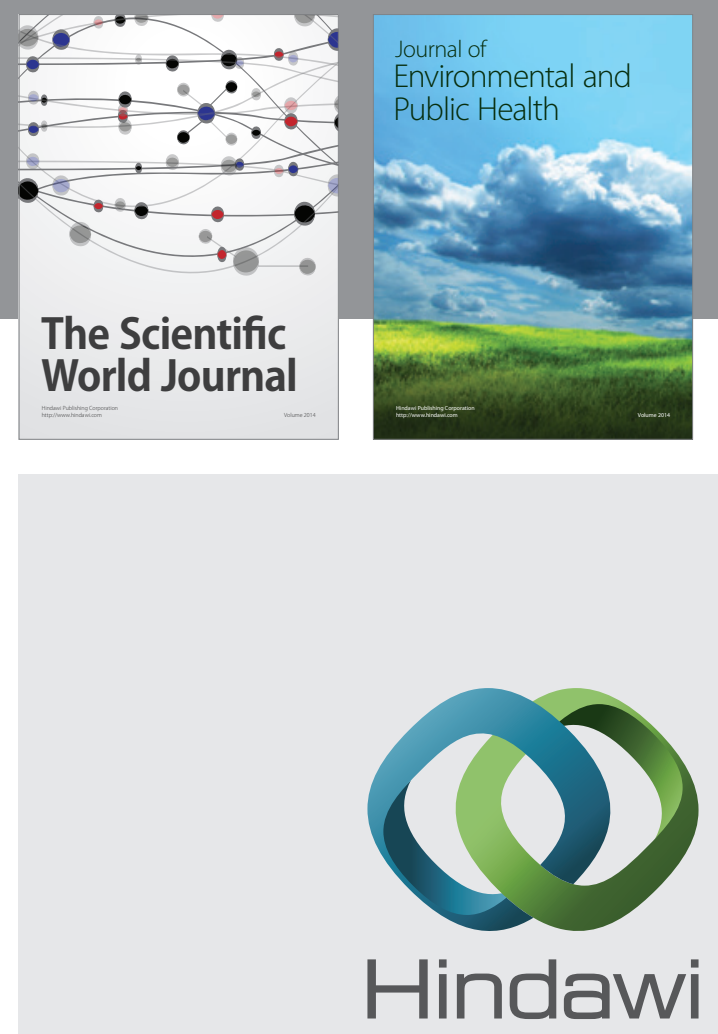

Submit your manuscripts at

http://www.hindawi.com
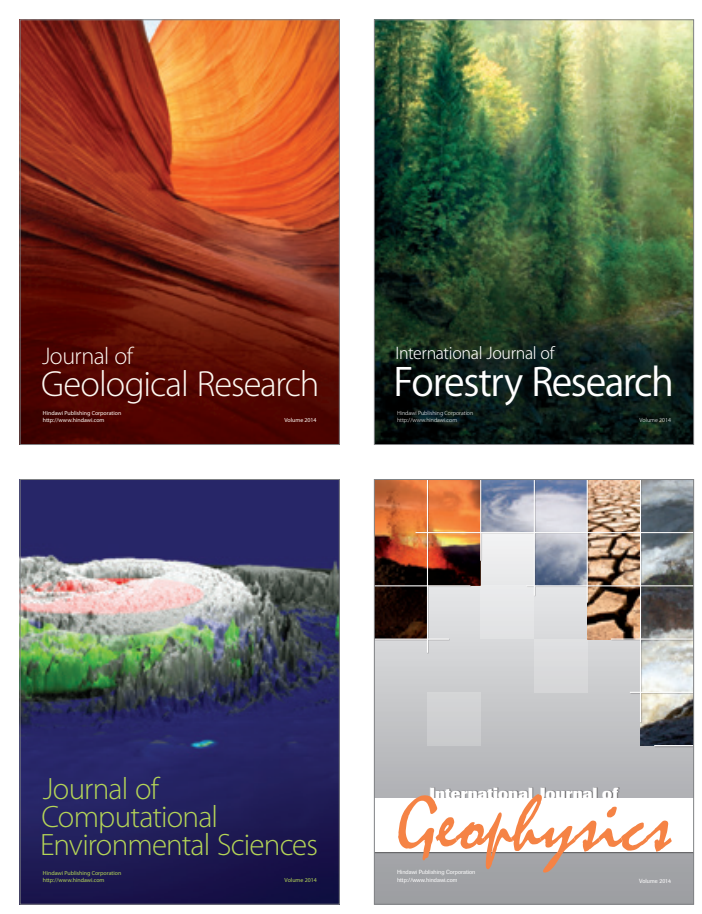
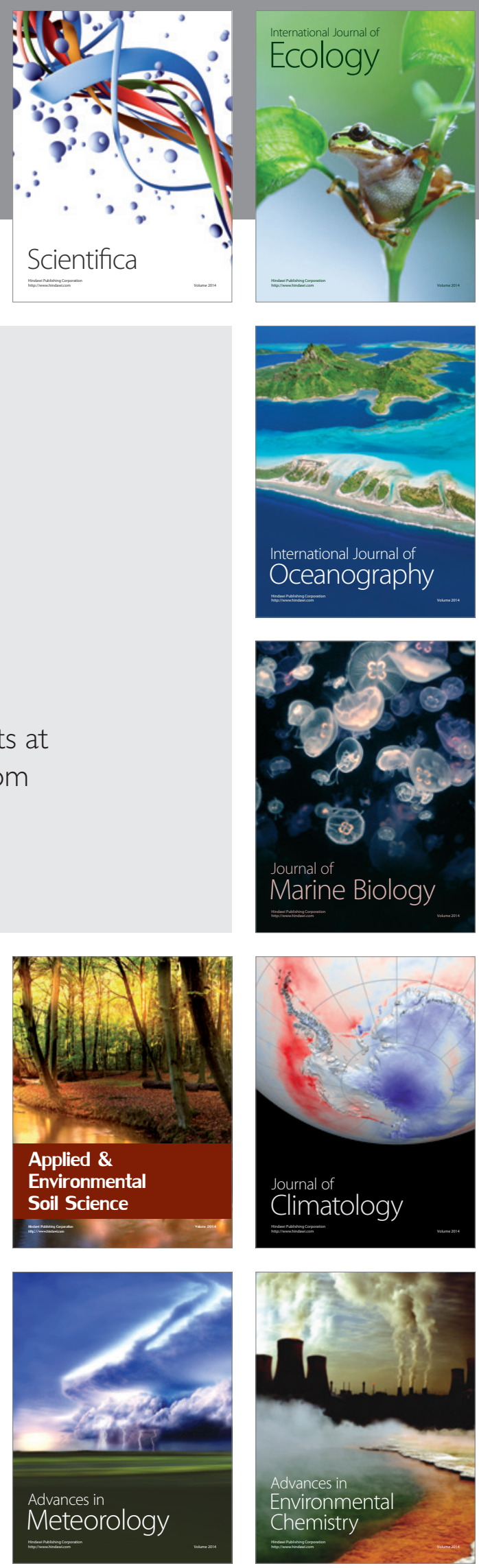